\title{
Memórias de Riobaldo: travessia
}

\section{Márcia Cristina Roque Corrêa Marques*}

\begin{abstract}
Resumo: $O$ presente trabalho procura analisar a travessia empreendida por Riobaldo, no romance Grande Sertão: Veredas, de Guimarães Rosa, em busca de sua verdadeira identidade. Tomou-se como foco principal somente a questão da transformação do personagem central ao longo da narrativa: do menino em jagunço, de Tatarana em Urutu-Branco e do Chefe em fazendeiro. Como ponto de partida, buscou-se analisar a construção da obra como autobiografia e a função da oralidade como forma narrativa. Como suporte ao relato em primeira pessoa e sua parcialidade do ponto de vista narrativo, buscou-se fazer um panorama do funcionamento $e$ da funcionalidade da memória no processo de construção da identidade de um indivíduo. Ao final, foi feito um cotejo entre as abordagens da memória apresentadas e análises críticas já realizadas sobre a obra, mostrando a transformação de Riobaldo e sua travessia interior.
\end{abstract}

Palavras-chave: Grande Sertão: Veredas; travessia; Riobaldo; autobiografia ficcional.

\begin{abstract}
This work aims at analyzing the journey made by Riobaldo, in the novel Grande Sertão: Veredas, by Guimarães Rosa, searching for his real identity. The main point of this analysis was the transformation of the main character along the narrative: from a little boy into a "jagunço", from "Tatarana" into "Urutu-Branco" and from the Chief Leader into a rancher. As a starting point, we tried to analyze the novel as an autobiography and also the role of oral expression as a narrative means. In order to support the first person report and its partial point of view, we tried to build a panorama of the function and the functionality of memory in the process of building an individual's identity. Finally, we made a comparison between the memory approaches here presented and some previous critical analysis about the novel, showing the transformation of Riobaldo and his internal journey.
\end{abstract}

Keywords: Grande Sertão: Veredas; journey; Riobaldo; fictional autobiography.

\section{A natureza autobiográfica e o ponto de vista narrativo}

Sabemos que o relato de Riobaldo é sobre sua própria vida, sua travessia, sua transformação. Através da conversa com o "Senhor", Riobaldo busca reconstituir seu passado, avaliar tudo que viveu e, através da interlocução que estabelece com seu ouvinte, buscar também certa pacificação interior. Esta pacificação vem sob a forma da confirmação de seus interlocutores, primeiro Quelemém e depois do Senhor, de que o diabo não existe e mais, de que seu amor interdito, bem como os atos que praticou ao longo de sua vida de jagunço, não fazem mais parte da vida do pacato fazendeiro de meia idade. Riobaldo quer a redenção.

\footnotetext{
* Mestranda do Programa de Pós Graduação em Letras da Universidade Federal do Rio Grande do Sul na área de Estudos da Literatura, Especialidade: Literaturas Brasileira, Portuguesa e Luso-Africanas. Possui Especialização em Literatura Brasileira pela mesma Universidade e faz parte do grupo de pesquisa sobre Crítica Genética e Acervos Literários, sob a orientação da Profa. Dra. Márcia Ivana de Lima e Silva. Atualmente pesquisa a relação entre as crônicas de Caio Fernando Abreu e a recepção de seus leitores. E-mail: mcroque@terra.com.br.
} 
A estratégia narrativa é brilhante. Sem divisão em capítulos, o livro se transforma numa narrativa de um fôlego só, como se a história de Riobaldo, a matéria vertente, jorrasse sobre o Senhor em forma de palavras. Simulando um relato oral, Riobaldo recorre à memória para reconstruir sua vida e transforma-se, ao mesmo tempo, em narrador e em personagem principal, não só de seu próprio relato, mas também da intrincada forma narrativa arranjada por Guimarães Rosa, que recorre ao diálogo entre Riobaldo e o Senhor para reconstruir a travessia espacial e interior do ex-jagunço pelo sertão das Gerais.

A tradição da narrativa oral esteve desde sempre em nosso meio, e PLATÃO (2007), em Fedro, propõe a discussão sobre a qualidade e funcionalidade da oratória, bem como do papel da memória nesta prática. Platão também coloca em discussão o papel da escrita, que em sua época, surgia e colocava em risco a arte narrativa.

Sobre a oratória, dizia PLATÃO ser esta a "arte de dirigir as almas" (ibidem, p.100) e que para o orador "não é indispensável conhecer o que de fato é justo, mas sim o que parece justo para a maioria dos ouvintes" (ibidem, p. 98). Ou seja, um orador, se bom conhecedor da chamada arte retórica, tem condições de persuadir através de seu discurso. "E quem fizer isso com arte não conseguirá que a mesma coisa pareça aos mesmos homens ora justa, ora injusta, como melhor lhe convier?" (ibidem, p. 101). O pensador grego ainda alerta para o fato de que somente "aquele que possui a verdade pode, facilmente, iludir seus ouvintes." (ibidem, p. 103). E é este poder de persuasão que Platão confere à arte retórica que somente pode ser estabelecido via comunicação oral, pois um bom discurso precisa ser vivo, ou seja, permitir a interlocução e o "compor e decompor idéias"(ibidem, p.107).

E é assim, nos moldes da retórica platônica, que a história de Riobaldo flui. Ele tem uma "tese" e deseja expô-la, em primeiro lugar, para depois, ao longo da narrativa de sua odisséia, convencer a si mesmo e obter a confirmação do letrado homem da cidade. Esta armação do texto é mostrada por ROSENFIELD (2006), que propõe a divisão da obra em três blocos, sendo que a narrativa em ordem cronológica propriamente dita somente ocorre na segunda parte, pois o início da história de Riobaldo nos traz fatos de diferentes épocas de sua vida, ora junto ao bando de Zé Bebelo, ora com os Hermógenes, ora com Medeiro Vaz. É na primeira parte que surgem os "causos" que Riobaldo usa para ilustrar sua "tese" de que a maldade humana é parte integrante de todos. Desfilam então os "causos" do Aleixo, de Pedro Pindó, de Jazevedão, do jagunço Joe Cazuzo, a tese da mandioca brava e da mandioca boa e o "causo" da Maria Mutema. Em todas as histórias, bem como na ausência de sequiência cronológica, o objetivo é ilustrar ao Senhor que a maldade só precisa de uma oportunidade 
para se mostrar e que vive nos "crespos do homem". Esta é sua estratégia para narrar sua história.

Riobaldo conhece sua verdade, ou aquilo que, através do processo de elaboração de sua experiência, teceu como verdade. Mas esta verdade precisa ser revisitada, pois há pontos "encobertos" e lacunas que ainda precisam ser preenchidas e, como grande orador, Riobaldo não busca, talvez, iludir seu interlocutor, mas preencher estes pontos e para tanto, ele arma seu discurso, primeiro com metáforas e depois com os fatos, "compondo e decompondo" suas idéias.

Sei que estou contando errado, pelos altos. Desemendo. Mas não é por disfarçar, não pense. De grave, na lei do comum, disse ao senhor quase tudo. Não crio receio. O senhor é homem de pensar o dos outros como sendo o seu, não é criatura de pôr denúncia. E meus feitos já revogaram, prescrição dita. Tenho meu respeito firmado. Agora, sou anta empoçada, ninguém me caça. [...] Eu estou contando assim, porque é o meu jeito de contar. Guerras e batalhas? Isso é como jogo de baralho, verte, reverte. [...] Contar seguido, alinhavado, só mesmo sendo as coisas de rasa importância. De cada vivimento que eu real tive, de alegria forte ou pesar, cada vez daquela hoje vejo que eu era como se fosse diferente pessoa. Sucedido desgovernado. Assim eu acho, assim é que eu conto. (ROSA, 2001, p. 114-115)

Essa forma de narrar ilustrando, indo e vindo e usando metáforas foi elogiada por Platão ao referir-se à arte retórica de Polos, que "fala em consonância, em repetições, em abuso de provérbios, alegorias [...]” (PLATÃO, 2007, p. 109). E assim é com Riobaldo, que ilustra suas teses com causos alegóricos, usa seus próprios provérbios como, por exemplo, "viver é muito perigoso" (ROSA, 2001) e sempre repete aquilo que é o fundamento de seu discurso: convencer o Senhor, e mais que este, a si mesmo, de que "o diabo não existe" (ROSA, 2001). Nestas escolhas que faz para ilustrar sua narrativa, Riobaldo se atém bastante ao que sabe ser verossímil, discernindo, conforme PLATÃO (2007), entre o que é possível e o que não é. Sua história traz relatos de pactos demoníacos, de travessias fantásticas, mas, ao final, Riobaldo dá a elas uma explicação lógica e que também faz parte de sua "verdade elaborada": tudo não passa de "crendices" do "povo prascóvio" que somente fizeram com que ele próprio conseguisse ver de forma errônea a coragem que nele habitava; em seus "avessos", funcionando com uma espécie de "placebo".

Nesse processo, Riobaldo também escolhe seu interlocutor, pois, precisa ser alguém capaz de entender a complexidade de sua narrativa e dar a ele uma confirmação que, por ser autorizada, lhe daria a paz e a redenção buscadas. Seu objetivo é expor sua alma e esta somente pode ser apreciada por uma alma que se sinta tocada pelo discurso riobaldiano.

É essa busca pela aprovação do outro para sua história e para a história que teceu sobre si mesmo que fazem deste ex-jagunço o narrador típico de Walter Benjamin (1994). Riobaldo é aquele que narra as ações da experiência, e não somente suas vivências. Muito embora não 
se "ouça" a voz do Senhor, ela está presente ao longo de toda a narrativa, conferindo-lhe o caráter dialógico da narração. Riobaldo "aprendeu" a ser o que é hoje ao ter passado por todos os fatos que narra, houve aprendizado e ele busca no Senhor, como buscou anteriormente em Quelemém, dar mais um salto nesta cadeia: confirmar que todo ser humano pode ser bom ou mau, alternando estes estados. Assim, com a confirmação de que seus atos de crueldade enquanto jagunço eram inerentes da condição humana e a revelação de que seu amor por Diadorim nunca foi realmente interdito, o pacato Riobaldo pode enfim firmar sua história de vida e se redimir.

O senhor é de fora, meu amigo mas meu estranho. Mas, talvez por isto mesmo. Falar com o estranho assim, que bem ouve e logo longe se vai embora, é um segundo proveito: faz do jeito que eu falasse mais mesmo comigo. Mire veja: o que é ruim, dentro da gente, a gente perverte sempre por arredar de si. Por isso é que o muito se fala?

$\mathrm{E}$ as idéias instruídas do senhor me fornecem paz. Principalmente a confirmação, que me deu, de que o Tal não existe. (ROSA, 2001, p.55)

Esta confirmação seria o que BENJAMIN (1994) chama de "conselho", ou de senso prático, pois a verdadeira natureza da narrativa é ser utilitária, transmitindo ensinamentos, dando conselhos. Como a natureza do conselho é eminentemente dialógica (o homem primeiro precisa verbalizar sua situação para que depois possa receber o conselho), se a verbalização das experiências está em declínio, a prática do conselho também está e com ela a transmissão da sabedoria, processo chamado por Walter Benjamin (1994) de o lado épico da verdade, termo retomado alguns anos mais tarde por José Hildebrando Dacanal (1988), que também se refere à experiência de Riobaldo como épica.

Este tipo de experiência comunicável é que se consolida como a fonte da qual se servem os narradores e como a fonte das melhores narrativas escritas. BENJAMIN (1994) classifica os melhores tipos de narradores em dois: um representado pela figura do camponês sedentário e outro pela figura do marinheiro. O primeiro seria aquele que, nunca tendo saído de sua terra natal, acumula experiências em torno da tradição; o segundo seria o que, viajando e conhecendo terras distantes, acumula experiências diversas, de outras realidades. Contudo, o melhor narrador é apontado como aquele que se forma da interpenetração destes dois tipos primários, conhecendo o arcabouço das experiências locais (mas também distantes no tempo da tradição) e estabelecendo relações de diversidade entre o local e imediato e o distante (espacial e temporal). Riobaldo é este narrador híbrido, que, tendo cruzado o sertão das Gerais, traz para seu ouvinte as experiências dos locais distantes e, apaziguado, como um fazendeiro, acumula experiências de sua terra e de sua travessia. 
Porém, vale ressaltar, que o narrador busca, no romance de Guimarães Rosa, obter o conselho e não dar-lhe, mas, de uma forma ou de outra, ambos os processos acabam por se estabelecer, pois sua narração é de natureza tão profunda, que acaba modificando seus ouvintes/leitores. Na busca de entender a si mesmo e ao seu passado, ele acaba transmitindo sua experiência e modificando seu entorno.

Contudo, se, por um lado, a narrativa riobaldiana está em consonância com a boa oratória prescrita por PLATÃO (2007) e com a funcionalidade atestada por Walter Benjamin (1994), não podemos nos esquecer que os textos destes dois pensadores se insurgem contra a escrita, que é o meio real de Grande Sertão: Veredas. Não podemos nos esquecer que tratamos de um romance (forma criticada por Benjamin) e que Riobaldo é, na verdade, fruto da concepção de um grande autor, Guimarães Rosa. Daí advém a complexidade desta estrutura narrativa que usa da oralidade, assim como o discurso platônico, mas é, na verdade, uma obra de ficção.

Riobaldo é, então, ao mesmo tempo, o narrador de PLATÃO (2007) e BENJAMIN (1994), mas é também o narrador do romance de Guimarães Rosa, cujo foco narrativo é parte essencial de sua construção. BOOTH (1967, p. 88) chama de clichê o debate que estabelece que o efeito dramático produzido por um narrador de terceira pessoa seja superior ao mero ato de contar uma história e chama ainda a atenção para o fato de que o ponto de vista narrativo é uma questão de técnica, um meio para que se atinjam fins maiores (ibidem, p.89). Riobaldo é um eu-protagonista que busca em sua memória uma ressignificação de sua existência.

Baseando-nos nestes dois fatos, surge um primeiro problema, exposto por FRIEDMAN (1967):

Com o deslocamento do fardo narrativo de uma testemunha para um dos protagonistas principais, que conta sua própria história em primeira pessoa, perdem-se alguns canais de informação e algumas vantagens. Em virtude de seu papel subordinado na história, o narradortestemunha tem muito mais mobilidade e, consequentemente, um maior número e variedade de fontes de informação do que o protagonista, que está centralmente envolvido na ação. Assim, o narrador-protagonista está, quase que inteiramente, limitado aos seus próprios pensamentos, sentimentos e percepções. (FRIEDMAN, 1967, p. 126-127, livre tradução da autora) ${ }^{1}$

Ou seja, a história de Riobaldo é retratada por ele mesmo, não temos outro ponto de vista ou outra fonte de informações além do próprio narrador, embora ele tente, seguindo a "receita" platônica, conferir veracidade aos fatos falando dos ex-companheiros que residem

\footnotetext{
${ }^{1}$ With the shift of the narrative burden from a witness to one of the chief protagonists, who tells his own story in the first person, a few more channels of information are given up and a few more vantage points are lost. Because of his subordinate role in the story itself, the witness narrator has much greater mobility and consequently a greater range and variety of sources of information than the protagonist proper, who is centrally involved in the action. The protagonist-narrator, therefore, is limited almost entirely to his own thoughts, feelings, and perceptions.
} 
em fazendas próximas e que podem ser chamados a qualquer hora para testemunhar. Contudo, o problema apontado por FRIEDMAN (1967) é referido por BOOTH (1967) como uma técnica para alcançar um fim maior, no caso de Grande Sertão: Veredas: conferir a este romance um caráter memorialistico. São as memórias de Riobaldo, via relato oral, que desfilam pelas páginas da obra, caracterizando-a quase como uma autobiografia, mas no plano do memorialismo fíctício.

Philippe Lejeune define a autobiografia como um "relato retrospectivo em prosa que uma pessoa real faz de sua própria existência, cuja ênfase é sobre a vida individual dessa pessoa, em particular sobre a história de sua personalidade" (LEJEUNE, 1996, p. 14, livre tradução da autora) $)^{2}$. O autor também define alguns elementos que são obrigatórios para que se caracterize o gênero como autobiográfico, sendo eles a forma da linguagem (relato e em prosa), o assunto tratado (vida individual, história de uma personalidade), a situação do autor (identidade entre autor e narrador) e a posição do narrador (identidade entre o narrador e a personagem principal e perspectiva retrospectiva do relato). Sendo assim, o memorialismo ficcional somente não atende a questão da identidade entre o autor e o narrador, pois não se trata da narração da vida real do autor, mas sim da vida de um personagem. Em Grande Sertão: Veredas, muito embora haja especulações em torno da identidade do Senhor, temos exatamente esta conformação, pois Riobaldo é um sujeito fictício, e é ele, e não o Senhor, quem narra sua própria vida. Mas todos os outros elementos são contemplados: temos um relato em prosa, o assunto tratado é a vida individual de Riobaldo e, na busca pela confirmação do Senhor de sua tese sobre a maldade humana, Riobaldo acaba traçando a gênese de sua personalidade atual, o narrador e a personagem principal do relato são os mesmos (Riobaldo) e a perspectiva, mesmo que fora de ordem cronológica na primeira parte, é sempre retrospectiva.

Ou seja, o foco narrativo está totalmente a serviço da estruturação do romance, que ao mesmo tempo em que segue o formato de um relato autobiográfico, utiliza-se também da forma do diálogo platônico para buscar a solução para o problema existencial de Riobaldo. Com o artifício da oralidade, a questão do ponto de vista narrativo também é, de certa forma, justificada, pois o único recurso de um relato oral é a arte retórica do narrador e sua memória, que pode falsear, selecionar e mascarar fatos, como faz um narrador-protagonista em romances.

\footnotetext{
${ }^{2}$ Récit retrospective en prose qu'une personne réelle fait de as propre existence, lorsqu'elle met accent sur as vie individuelle, em particulier sur l'histoire de sa personnalité.
} 


\title{
2 A questão da memória
}

A memória é um tema de interesse em diversas áreas, como, por exemplo, na medicina, na filosofia e no campo dos estudos literários e, no caso de Grande Sertão: Veredas, é de importância capital, pois é nela que Riobaldo se ampara para contar os fatos e é ela que confere à esta trama ficcional semelhanças com o gênero autobiográfico.

No campo da medicina, Ivan Izquierdo (2006) define a memória como sendo "a aquisição, conservação e evocação de informações. A aquisição se denomina também aprendizado. A evocação também se denomina recordação ou lembrança. Só pode se avaliar a memória por meio da evocação." (IZQUIERDO, 2006, p. 15). O autor também afirma que "a passagem do tempo faz com que as memórias remotas sejam mais suscetíveis ao esquecimento e à extinção, assim como à inclusão de informação adicional, que as melhora ou falsifica." (ibidem, p. 23).

A questão da falsificação da memória interessa bastante a este estudo, uma vez que, no decorrer de seu discurso, Riobaldo afirma diversas vezes que está falseando suas memórias, ou selecionando passagens, como no trecho a seguir,

\begin{abstract}
Ah, mas falo falso. O senhor sente? Desmente. Eu desminto. Contar é muito, muito dificultoso. Não pelos anos que se já passaram. Mas pela astúcia que têm certas coisas passadas - de fazer balance, de se remexerem dos lugares. O que eu falei dói exato? Foi. Mas teria sido? Agora, acho que nem não. São tantas horas de pessoas, tantas coisas em tantos tempos, tudo miúdo recruzado. (ROSA, 2001, p. 200)
\end{abstract}

Em outro de seus estudos, Ivan Izquierdo afirma que podemos falsear memórias não só voluntariamente, mas também porque "muitas das misturas que fazemos entre memórias ocorrem pelo predomínio do afeto sobre a precisão.” (IZQUIERDO, 2004, p. 61). Ou ainda por sugestionamento, ou porque "precisamos acreditar em algo bom a respeito de nós mesmos e de nossos referenciais. É muito difícil ter que conviver com um passado pessoal muitas vezes sombrio, com referenciais falhos (...)" (ibidem, p. 62). Isso ocorre devido ao fato de que emoção e memória caminham lado e lado e, portanto, o papel das emoções no momento da evocação pode acarretar em falseamento do que recordamos. O próprio Riobaldo está bem ciente disso quando diz que "a gente se acha de voltar aos passados, mas parece que escolhidas só as peripécias avaliáveis, as que agradáveis foram.” (ROSA, 2001, p. 87).

IZQUIERDO (2004) também afirma que somos uma mistura daquilo que lembramos, daquilo que decidimos esquecer e daquilo que conseguimos; que

nosso acervo de memórias consiste mais de fragmentos ou de memórias extintas ou quase extintas, do que de memórias completas. Mas com esses fragmentos e uma boa dose de 
imaginação (ou falsificação) podem-se construir até obras-primas, como a genial autobiografia de García Márquez. (IZQUIERDO, 2004, p. 107)

Assim, pela repetição de sua história, Riobaldo vai se construindo e elaborando, proporcionando aos leitores um mergulho em seu acervo memorialístico. Não sabemos quanto de verdade há em seu relato, mas sabemos como o narrador, ao longo dos eventos que vivenciou se construiu como o pacato fazendeiro contador de causos, bem casado com sua Otacília, temente a Deus e que tem certeza (ou não) de que o diabo não existe.

Interessante observar que esta reconstrução se dá sempre pela oralidade e que Riobaldo repete para não esquecer. BENJAMIN (1994) faz uma definição a respeito da faculdade da memória, originada da musa Mnemósine, que sofreu uma espécie de divisão com o declínio do épico e a ascensão do romance. Se na narração a faculdade da memória está no campo das reminiscências que são justapostas como um todo unificado, no romance estamos no campo das recordações. A primeira é coletiva e efêmera e narra episódios de uma aventura e um herói, e a segunda é eternizante e individual (do romancista), narrando muitos eventos difusos. E, realmente, são as reminiscências justapostas de Riobaldo que formam a aventura de um herói que teve um tipo de angústia com a qual muitos se identificam. E nesse exercício, ele exercita a memória de si, conforme diz a medicina de Ivan Izquierdo (2004) e a filosofia de PLATÃO (2007). "Por tudo, réis-coado, fico pensando. Gosto. Melhor, para a idéia se bem abrir, é viajando em trem-de-ferro. Pudesse, vivia para cima e para baixo, dentro dele. (ROSA, 2001, p. 37).

Um outro aspecto interessante a respeito da memória é o levantado por Ecléa Bosi (1994). Retomando, Henri Bergson, a autora faz uma ligação entre a constante reconstrução de nossas memórias passadas e a imagem que temos de nós mesmos no presente, pois há, para sustentar a teoria de Bergson, o

[...] pressuposto de uma conservação subliminar, subconsciente, de toda a vida psicológica já transcorrida. Somos tentados, na esteira de Bergson, a pensar na etimologia do verbo. "Lembrar-se", em francês se souvenir, significa um movimento de "vir" "de baixo": sousvenir, vir à tona o que estava submerso. Esse afloramento do passado combina-se com o processo corporal e presente da percepção: “Aos dados imediatos e presentes de nossos sentidos nós misturamos milhares de pormenores da nossa lembrança passada. Quase sempre essas lembranças deslocam nossas percepções reais, das quais retemos então apenas algumas indicações, meros 'signos' destinados a evocar imagens antigas”. (BOSI, 1994, p. 46)

A lembrança, então, é sempre um construto de nosso passado associado ao nosso presente. Somos, no presente, aquilo que lembramos e que ajudou a nos construir como tal e "a percepção concreta precisa valer-se do passado que de algum modo se conservou; a memória é essa reserva crescente a cada instante e que dispõe da totalidade da nossa 
experiência adquirida.” (BOSI, 1994, p. 47). Riobaldo, então, se valeria da experiência passada (o pacto que não existiu) para afirmar suas memórias presentes, mas como a dúvida faz parte de suas memórias, ele precisa dialogar com o outro para buscar suas certezas. "O passado conserva-se e, além de conservar-se, atua no presente mas não de forma homogênea." (ibidem, p. 48). Sob esta perspectiva, associada à de IZQUIERDO (2004), somos o resultado de nossas memórias (experiências), mas esta construção não se dá de forma consciente:

Antes de ser atualizada pela consciência, toda lembrança "vive" em estado latente, potencial.
Esse estado, porque está abaixo da consciência atual ("abaixo" metaforicamente), é qualificado
de "inconsciente". [...] A própria ação da consciência supõe o "outro", ou seja, a ação de
fenômenos e estados infraconscientes que costumam ficar à sombra. É precisamente nesse
reino de sombras que se deposita o tesouro da memória. (BOSI, 1994, p. 51-52)

É nesse reino de sombras que está toda a vida de Riobaldo e que ele traz a tona quando estabelece a interlocução. Éclea Bosi (1994) vai mais além e busca apoio em outro teórico para complementar as idéias bergsonianas. Segundo a autora,

[...] a lembrança bergsoniana, enquanto conservação total do passado e sua ressurreição, só seria possível no caso (afinal, impossível) em que o adulto mantivesse intacto o sistema de representações, hábitos e relações sociais de sua infância. A menor alteração do ambiente atinge a qualidade íntima da memória. Por essa via, Halbwachs amarra a memória da pessoa à memória do grupo; e esta última à esfera maior da tradição, que é a memória coletiva de cada sociedade.(BOSI, 1994, p. 55)

Assim, a memória fragmentada de Riobaldo precisa ser preenchida, e a construção de sua identidade estaria ligada não somente às lembranças e sensações que ele conseguiu armazenar em seu subconsciente, mas também ao grupo social no qual esteve inserido, no caso, os bandos jagunços, e é sob a consciência do fazendeiro, que estas memórias emergem, gerando um todo que se atualiza a cada rememoração. Um dos pontos de conflito de Riobaldo é seu pertencimento ao bando de jagunços, coisa que sua consciência letrada (cf. DACANAL, 1988) rejeitou durante a maior parte de sua vida, mesmo nos momentos em que o personagem estava em meio aos jagunços, sempre gerando dúvidas e incertezas sobre sua função em meio ao bando. No momento em que narra sua trajetória ao Senhor, a consciência do fazendeiro rejeita totalmente a violência do mundo jagunço, mesmo que esta violência o tenha dominado em determinadas etapas de sua vida. Quem narra é o Riobaldo fazendeiro, e toda sua trajetória está sob o crivo e o juízo de valor deste e não do jagunço Tatarana ou do Urutu-Branco. Nem tampouco do homem que se apaixonou por outro, mas de um fazendeiro que já sabe que o outro jagunço era uma mulher. Há necessidade de expor este relato, talvez para fixar as imagens daqueles episódios como ele os vê hoje. 
A autora traz também à tona o papel social da memória, ou seja, na atividade narrativa ao moldes de Walter Benjamin (1994), reside a verdadeira transmissão de conhecimento e cultura, através da narração do que a autora chama de "histórias de velhos", pois

O adulto ativo não se ocupa longamente com o passado; mas, quando o faz, é como se este lhe sobreviesse em forma de sonho. Em suma: para o adulto ativo, vida prática é vida prática, e memória é fuga, arte, lazer, contemplação. É o momento em que as águas se separam com maior nitidez.

Bem outra seria a situação do velho, do homem que já viveu sua vida. Ao lembrar o passado ele não está descansando, não está se entregando fugitivamente às delícias do sonho: ele está se ocupando consciente e atentamente do próprio passado, da substância mesma da sua vida. (BOSI, 1994, p. 60)

Ou seja, a matéria vertente de que fala o velho Riobaldo.

Dentro deste panorama, verificamos que o papel da memória na narrativa de Riobaldo é fator constituinte não só da trama narrativa do romance, mas também da organização interna da história que está sendo contada. É através da memória que o velho Riobaldo reavalia seu passado e constrói sua identidade presente, é através da reconstituição de seu passado, a partir dos fragmentos de que dispõe, que ele se atualiza e pede conselhos, mas também transmite o legado cultural e histórico do momento em que viveu, pois muitas recordações e, principalmente opiniões sobre o que foi vivido, foram sendo construídas ao longo da vida de Riobaldo, mescladas ao meio em que o personagem viveu e vive, e às emoções que suas lembranças ainda suscitam.

Nesse relato, Riobaldo empreende, mais uma vez, a travessia pelo sertão, não das Gerais, mas dentro de si.

\section{A travessia}

Riobaldo, conforme já foi dito anteriormente, empreende, através de sua memória e da interlocução com o Senhor, buscar respostas para questões indefinidas de sua vida. O narrador confunde-se, ora diz uma coisa, logo após a contradiz e empreende a verdadeira travessia de si mesmo e depara-se com as dificuldades da tarefa à qual se propôs. Na interpretação de Katrin Rosenfiled, "a matéria vertente é o que impede Riobaldo de chegar ao fim de sua tarefa: as reviravoltas não apenas individuais, mas inscritas em todas as coisas e experiências humanas.” (ROSENFIELD, 2006, p. 201). A autora atesta também que esta dificuldade devese à opacidade da memória, conceito que toma de Walter Benjamin e que afirma que

[...] o passado não está disponível, à nossa espera, nas reminiscências que guardamos da nossa vida pregressa ou nos fatos positivos que ocorreram nela. $\mathrm{O}$ ocorrido e o vivido de um lado, do outro, a poesia e a narrativa, comportando essa última um alto grau de densidade poética: 
nebulosas de sentido que conservam um segredo opaco e resistente à compreensão imediata. (ROSENFIELD, 2006, p. 205)

Narrar é, portanto, a travessia dentro da nebulosa da memória.

O senhor sabe? Não acerto no contar, porque estou remexendo o vivido longe alto, com pouco caroço, querendo esquentar, demear, de feito, meu coração, naquelas lembranças. Ou quero enfiar a idéia, achar o rumorzinho forte das coisas, caminho do que houve e do que não houve. Às vezes não é fácil. Fé que não é. Mire veja: naqueles dias, na ocasião, devem ter acontecido coisas meio importantes, que eu não notava, não surpreendi em mim. Mesmo hoje não atino com o que foram. (ROSA, 2001, p. 192)

O interlocutor é quem ajuda o ex-jagunço a encontrar essa verdade ao fim da travessia, pois, como ele mesmo diz, "resumo; não gloso. No fim, o senhor me completa." (ROSA, 2001, p. 531) e "no que narrei, o senhor talvez até ache mais do que eu, a minha verdade. Fim do que foi." (ibidem, p. 616).

O leitor, ao acompanhar o fio da narrativa riobaldiana se depara, na segunda parte do romance, com um menino pobre que perdeu a mãe e é enviado ao seu pai biológico que se apresenta como seu padrinho. No encontro com o menino Reinaldo, o menino Riobaldo descobre o que é a coragem e descobre que não a tem, fascinando-se com a postura de Reinaldo. Numa tentativa de atrair a admiração do pai/padrinho, foge de casa e acaba como jagunço do bando de Zé Bebelo, "profissão" à qual seu pai credita a maior valia e coragem possíveis. A partir desse ponto, vemos Riobaldo lutando contra o medo da guerra, contra o medo do demo e contra o medo de si mesmo, através dos sentimentos que nutre por Diadorim. O fazendeiro Riobaldo sabe que Diadorim é, na verdade, uma mulher, mas não revela essa informação, penitencia-se durante toda a narrativa, somente revelando o segredo ao Senhor no final de seu relato. $\mathrm{O}$ fazendeiro Riobaldo sabe de todas as provações pelas quais o jagunço Tatarana e o Chefe Urutu-Branco passaram para descobrir a coragem e remover parte da nebulosa que encobre suas memórias. E é também o fazendeiro Riobaldo que faz o relato como uma tentativa de preencher as lacunas que ainda persistem na história que criou de si mesmo.

Antônio Candido (2006) faz uma análise bastante interessante dessa travessia, mostrando a influência do espaço do Sertão sobre a personalidade de Riobaldo, apontando alguns aspectos interessantes dessa sua travessia interior. Segundo o autor, o meio físico é uma "realidade envolvente e bizarra, servindo de quadro à concepção do mundo e de suporte ao universo inventado." (CANDIDO, 2006, p.113). Nesta análise, Antônio Candido afirma que o Rio São Francisco divide os acontecimentos da vida de Riobaldo, sendo que numa das margens ocorrem os acontecimentos claros e na outra, os acontecimentos que ainda se encontram encobertos pela neblina da memória. E o próprio Riobaldo afirma que, "o São 
Francisco partiu minha vida em duas partes. [...] Zé Bebelo me alumiou. [...] Meu coração é que entende, ajuda minha idéia a requerer e traçar.” (ROSA, 2001, p. 326).

CANDIDO (2006) aponta a margem direita como sendo o lugar onde se encontram o fasto, a topografia nítida e as relações mais normais (é onde estão Joca Ramiro, Zé Bebelo, a vida no Curralinho e a amizade com o menino Reinaldo), e a margem esquerda como o lugar onde se encontram o nefasto, a topografia mais fugidia, os imaginários e os fatos estranhos e desencontrados (é onde estão o Liso do Sussuarão, a casa de Hermógenes, as Veredas Mortas/Altas, o campo de batalha do Tamanduá-tão).

Na confusão das reminiscências de Riobaldo, a topografia se torna variável conforme a situação. O local do pacto, chamado durante toda a narrativa de Veredas Mortas, após a morte de Diadorim passa a ser chamado de Veredas Altas (seu verdadeiro nome). O Liso do Sussuarão que se mostrara um espaço impenetrável sob o comando de Medeiro Vaz, se entrega mítica e facilmente à bravura do Urutu Branco. Estas transformações dos espaços, na interpretação de CANDIDO (2006), mostram a adesão do homem ao mundo físico, sendo essa uma das tônicas da narração das transformações de Riobaldo, que quanto mais se entrega à vida de jagunço, mais se embrutece. Este embrutecimento vem associado ao espaço do Sertão, pois, "o senhor sabe: sertão é onde manda quem é forte, com as astúcias." (ROSA, 2001, p. 35). Somente ao final da narrativa sabemos que este Sertão a que Riobaldo se refere está dentro dele, e que atravessar o espaço físico foi quase que como uma metáfora da travessia de si mesmo: "No coração da gente, é o que estou figurando. Meu sertão, meu regozijo!" (ibidem, p. 487).

Na concepção de Riobaldo, para integrar-se a esse meio, a única alternativa é o embrutecimento, pois jagunços são "sertanejos tão sofridos. Jagunço é homem já meio desistido por si... A calamidade de quente! E o esbraseado, o estudo, a dor do calor em todos os corpos que a gente tem." (ibidem, p. 67). Além disso, a figura do jagunço está associada a uma coragem plácida, a de aceitar como parte da vida as durezas que lhe fossem apresentadas: "Jagunço não se escabreia com perda nem derrota - quase que tudo para ele é o igual. Nunca vi. Pra ele a vida já está assentada: comer, beber, apreciar mulher, brigar, e o fim final." (ibidem, p. 72).

Contudo, essa adesão que Riobaldo vai sofrendo ao se integrar aos bandos de jagunços não é completamente aceita e, com a morte de Diadorim, vem a certeza de que ele não pertence mesmo àquele lugar. Para Antônio Candido (2006), o jagunço era uma representação quase mítica de um tipo humano. 
Dentro dessa concepção de espaço e homem mítico, José Hildebrando Dacanal (1988) faz uma análise da travessia, como sendo a vitória de um plano de consciência lógico-racional sobre um plano mítico sacral, cujo detonador foi a educação de Riobaldo, que, superior a do meio no qual estava inserido, lhe permitia questionar o mundo ao seu redor e a realidade dos homens e da vida que levava como jagunço.

Nesta análise, o presente seria o último estágio da travessia de Riobaldo, que não pode negar o passado mítico, pois negá-lo seria negar a travessia e o estado atual de sua consciência, que nega o pacto, mas não os fatos. Se pensarmos sobre o que foi anteriormente exposto a respeito da memória, veremos que muito da análise de DACANAL (1988) se baseia na função que a memória de Riobaldo exerce na construção de sua identidade. Ele quer negar o pacto, buscando uma explicação lógica para o que ocorreu, mas não tem como negar seu passado, pois é dele que sua consciência presente se nutre. Apesar disso, ele não o aceita, pois há um conflito entre as duas consciências. Riobaldo faz uma "valoração do passado como experiência vital, imanente, positiva, portanto, épica." (DACANAL, 1988, p. 69) e é nesse ponto que José Hildebrando Dacanal se aproxima de Walter Benjamin (1994), conforme mencionado anteriormente.

DACANAL (1988) também afirma que Riobaldo não pode mais repetir a travessia, pois a jagunçagem pertence a um tempo mítico. Assim sendo, a única forma de revisitar esse passado e tentar afastar a neblina restante é através da memória.

Nesse processo de suplantação de um plano de consciência por outro, vemos a evolução da personalidade de Riobaldo, que de menino vira professor, passando a jagunço e, devido a sua destreza ao atirar, ganha o apelido de Tatarana, a lagarta de fogo. Num primeiro momento, sob o crivo do julgamento do fazendeiro Riobaldo, ao encontrar-se em meio aos jagunços, o narrador afirma que, "a verdade que diga, eu achava que não tinha nascido para aquilo, de ser sempre jagunço, não gostava.” (ROSA, 2001, p.82). Mas com o passar do tempo, junto ao bando dos "Medeiro-Vaz" e sob a influência da coragem de Diadorim, Riobaldo começa a questionar seu lugar naquele mundo. Mesmo sabendo que não pertencia àquele lugar, começa a se ver tão sem destino e sem futuro quanto os jagunços que, de certa forma, desprezava.

De seguir assim, sem a dura decisão, feito cachorro magro que espera viajantes em ponto de rancho, o senhor quem sabe vá achar que eu seja homem sem caráter. Eu mesmo pensei. Conheci que estava chocho, dado no mundo, vazio de meu dever honesto [...] e eu não pertencia a razão nenhuma, não guardava fé e nem fazia parte. (ROSA, 2001, p. 157-158) 
Com o passar do tempo, assimila seu próprio embrutecimento, e chega à conclusão que "eu estava ali era feito um escravo de morte, sem querer meu, no puto de homem, no danatório. [...] Tem um ponto de marca, que dele não se pode mais voltar para trás." (ROSA, 2001, p. 229). Foi nesse ponto em que Riobaldo descobriu que não se podia mais voltar atrás que assumiu a identidade de Tatarana: "Daquilo tudo eu gostei, gostava cada dia mais. Fui aprendendo a achar graça no dessossego." (ibidem, p. 263). Sem saber o que buscava, nem mesmo onde encontrar tal coisa, Riobaldo submerge no universo e na lógica jagunça.

O Tatarana logo começa a ceder espaço a uma outra personalidade, a uma personalidade que se sentia inferiorizada por Hermógenes (ROSENFIELD, 2006) e que aceita a existência do pacto como a única forma de suplantar seu medo e, miticamente, igualar-se ao oponente. Nesse momento, ele começa a sentir-se novamente diferente do bando de jagunços, mas essa diferença agora passa a ser marcada por uma consciência de sua superioridade em relação aos companheiros: "Parecia que era só eu que quem tinha responsabilidade séria neste mundo; confiança eu mais não depositava em ninguém.” (ROSA, 2001, p. 423). A coragem de Diadorim e o poder quase sobrenatural de Hermógenes passam, neste momento, a coexistir dentro de Riobaldo, mesmo que transitória e ilusoriamente.

Esta sensação que pouco a pouco ia lhe invadindo, lhe estimulava a querer alçar vôos mais altos, "eu queria ser mais do que eu." (ibidem, p. 437). A coragem, objeto de seu desejo, passou a ser confundida com a imagem daqueles que, em sua ilusão, a possuíam. Ele precisava ser/estar corajoso e bravo, mesmo que para tanto tivesse que vender sua alma ao demônio, que em sua imaginação, era responsável pelas façanhas de Hermógenes. O traidor deixa de ser objeto de repúdio, para, em seu íntimo, passar a ser objeto de admiração por possuir aquilo que ele almejava e que via também em Diadorim. Então, o desejo de comando, antes renegado, começa a aflorar, pois nesta posição, a imagem de homem bravo lhe estaria assegurada e, através do pacto, seu interior lhe garantiria que agora ele era como Hermógenes e Diadorim, podendo enfrentar o primeiro e ganhar a admiração do segundo.

Com o crescente descrédito de Zé Bebelo como chefe, vai surgindo em Tatarana o Urutu-Branco, que ao tomar o comando, não se interessa pela guerra, mas pelas demonstrações de medo e respeito que os outros pudessem lhe dar. Tomado da certeza de sua valentia com a qual o falso pacto lhe tinha imbuído, o Urutu-Branco sente-se fortalecido. Assim, o bando empreende uma série de viagens para que o novo Chefe possa ser reverenciado; nessa etapa da travessia, Riobaldo muda completamente sua perspectiva com relação ao seu pertencimento ao bando, não como jagunço, mas como chefe, "Eu bem que tinha nascido para jagunço" (ibidem, p. 466) e nesse momento vem também uma certeza, 
“quem mandava em mim já eram os meus avessos." (ibidem, p. 486). Nesse momento da narração, tece-se a teia que levara o fazendeiro Riobaldo a usar os causos como forma de ilustração em sua retórica, pois a maldade humana, que segundo a lógica destes causos, é inerente a todo ser humano e coexiste dentro de nós com aquilo que temos de bom, precisando somente de uma situação conveniente para aflorar, tinha vindo à tona também nele.

É em meio à batalha final contra o bando dos Hermógenes que o Urutu-Branco cede lugar novamente ao Tatarana. "Eu comandava? Um comanda é com o hoje, não é com o ontem. Aí eu era Urutu-Branco: mas tinha de ser o cerzidor; Tatarana, o que em ponto melhor alveja." (ibidem, p.597). No momento do combate, do alto da torre, na posição do Chefe, o cerzidor sela seu destino. A falsa coragem, garantida pelo suposto pacto, lhe falta e diante de seus olhos surge morto o objeto de seu desejo e admiração. E com a morte de Diadorim, Tatarana também desaparece, deixando o vazio do amor não realizado e da coragem fantasiada por meio de um pacto que mesmo o Riobaldo fazendeiro não sabe se existiu. Emerge então a consciência do homem velho que sabe hoje o que o jovem de ontem não sabia:

Ah, naqueles tempos eu não sabia, hoje é que sei: que para a gente se transformar em ruim ou em valentão, ah basta se olhar um minutinho no espelho - caprichando de fazer cara de valentia; ou cara de ruindade! Mas minha competência foi comprada a todos custos, caminhou com os pés da idade. (ROSA, 2001, p. 62)

Essa competência comprada com os pés da idade lhe trouxe também a explicação para sua vida, que hoje precisa ser vivida e revivida pela memória para que sua nova conformação se sustente: "E ainda hoje, o suceder deste meu coração copia é o eco daquele tempo; e qualquer fio de meu cabelo branco que o senhor arranque, declara o real daquilo - sem trabalho - sem traslado..." (ibidem, p. 481). Vem também a consciência da instabilidade de sua personalidade, "acho que eu não era capaz de ser uma coisa só o tempo todo.” (ibidem, p. 485) e que durante a travessia, sua busca era por coragem, uma coragem que via em Reinaldo/Diadorim e que, além do amor, lhe inspirava a seguir o jagunço.

\footnotetext{
Nasci para ser. Esbarrando aquele momento, era eu, sobre vez, por todos, eu enorme, que era, o que mais alto se realçava. E conheci: ofício de destino meu, real, era o de não ter medo. Ter medo nenhum. Não tive! Não tivesse, e tudo se desmanchava delicado para distante de mim, pelo meu vencer: ilha em águas claras... Conheci. Enchi minha história. (ROSA, 2001, p. 607)
}

Mas esta descoberta precisa ser avalizada pelo homem da cidade, que precisa, de certa forma, confirmar que o diabo não existe e que sua coragem sempre esteve com ele, necessitando do mito do pacto para aflorar. Só então, apaziguado, o fazendeiro Riobaldo pode, quem sabe, preencher algumas das lacunas ainda encobertas pelo véu da memória. 
Através da travessia, agora empreendida pela memória e através desta, Riobaldo desvenda seu

Sertão, e ao concluir sua tese, conclui-se. Pelo menos até a próxima vez em que o velho Riobaldo volte a transitar em meio a sua neblina.

"Nonada. O diabo não há! É o que eu digo, se for... Existe é homem humano. Travessia." (ibidem, p. 624).

\section{Referências}

BENJAMIN, Walter. O narrador: considerações sobre a obra de Nikolai Leskov. In:

Obras Escolhidas: magia e técnica, arte e política. São Paulo: Editora Brasiliense, 1994. p. 197-221. Trad. Sérgio Paulo Rouanet.

BOOTH, Wayne C. Distance and Point-of-View: an Essay in Classification. In: STEVICK, Philip. The theory of the novel. USA: The Free Press, 1967. p. 87-107.

BOSI, Éclea. Memória e Sociedade: lembranças de velhos. São Paulo: Companhia das Letras, 1994.

CANDIDO, Antônio. O Homem dos Avessos. In: . Tese e Antítese. Rio de Janeiro: Ouro sobre Azul, 2006. p. 111-130.

DACANAL, José Hildebrando. A Nova Narrativa Épica no Brasil. Porto Alegre: Mercado Aberto, 1988.

FRIEDMAN, Norman. Point of View in Fiction: the Development of a Critical Concept. In; STEVICK, Philip. The theory of the novel. USA: The Free Press, 1967. p. 108-139.

IZQUIERDO, Ivan. A arte de esquecer. Rio de Janeiro : Vieira \& Lent, 2004. . Questões sobre Memória. São Leopoldo : Editora da UNISINOS, 2006.

LEJEUNE, Philippe. Le pacte autobiographique. Paris : Éditions du Seuil, 1996.

PLATÃO. Fedro. São Paulo: Editora Martin Claret, 2007.

ROSA, João Guimarães. Grande Sertão: Veredas. Rio de Janeiro: Nova Fronteira, 2001.

ROSENFIELD, Kathrin Holzermayr. Desenveredando Rosa: A obra de J. G. Rosa e outros ensaios rosianos. Rio de Janeiro: Top Books, 2006. 